DOI: 10.1515/auseb-2015-0005

\title{
Businesses and Their Attitudes to Frugal Innovation
}

\author{
Ildikó MAROSI \\ Keleti Faculty of Business and Management, Óbuda University \\ E-mail: marosi.ildiko@kgk.uni-obuda.hu \\ Ferenc KATONA \\ Keleti Faculty of Business and Management, Óbuda University \\ E-mail: katona.ferenc@kgk.uni-obuda.hu
}

\begin{abstract}
In order to maintain and increase their market share and position in competition, businesses have to adapt to the changes of the environment and they have to innovate. Since the latest economic crisis, Hungarian businesses have been struggling with several problems, particularly the scarcity of both resources and demands. These circumstances lead to the issues of frugal innovation and sustainable development. The aim of this paper is to show the results of a survey on attitudes toward frugal innovation, which was conducted among 216 Hungarian enterprises in the spring of 2015. However, the surveyed businesses are striving to stay in competition in a not too favourable economic environment as most of them have not recognized the chance of frugal innovation.
\end{abstract}

Keywords: frugal innovation, Hungarian businesses, sustainability JEL Classification: $\mathrm{O} 35$

\section{Introduction}

Among several other new challenges for businesses in the $21^{\text {st }}$ century, particularly important requirements are: cost-effective management with resources, sustainable development, and globalization. Csath (2015) evaluates the latest IMF report about Hungary (2015), and his main point is that in Hungary the GDP has not reached the level we had before the economic crisis. The most important tasks aimed to boost competitiveness are: (i) diversifying the economic structure, which means increasing SMEs; (ii) moving from assemble work to create higher added value; (iii) more innovation that creates new jobs with higher qualifications and increases productivity. But a few conditions for sustainable development in Hungary are 
lacking. The issue of the environmental problems of the 1970s called for the notions of sustainable development and social responsibility. According to the United Nations World Commission on Environment and Development, sustainable development means "development that meets the needs of the present without compromising the ability of future generations to meet their own needs". In terms of the triple bottom line, there is environmental, societal, and economic sustainability (Tóth, 2007). The problem is a strong reductionism in business practice, where environmental sustainability is taken to mean eco-efficiency, societal sustainability is confused with insisting on principles such as the improvement of work conditions, and economic sustainability is identified as profitable, long-term competitiveness (Tóth, 2007 , p. 23). The practice of frugal innovation is regularly connected to emerging economies, particularly to India, and involves innovation under conditions of scarcity (Srinivas \& Sutz, 2008; Balkrishna, 2014). According to Berm and Ivens (2013), local governments in countries such as China, India, Russia, and Brazil emphasize their political concern about companies, sustainability management, and managerial attention. Based on Zeschky et al. (2011), it is obvious that a number of innovations stem from emerging economies, particularly the subsidiaries of multinational companies. Fukuda and Watanabe (2011, p. 95) emphasize that frugality is "a key to new functionality satisfying local demand of people in growing economies. [..] Frugality would trigger the shift from an autarky cycle between the consumption and GDP increases, to investment driven development."

There is an important and exciting question: How are businesses and particularly small- and medium-sized companies able to operate and innovate in difficult situations like that described above? The answer would be a frugal innovation, based on, among others, frugality or scarcity of resources. But the realization of innovation - like several other business activities - highly needs the positive attitudes of businesses. The aim of this paper is to examine these attitudes among Hungarian enterprises. The added value of the present paper is the analysis of the importance of frugal innovation and the feasibility of frugal innovation among Hungarian businesses.

The next section of the present paper deals with the definitions, essence, and characteristics of frugal innovation. The third section describes the materials and methods of our primary survey. Data and analyses can be found in the fourth section. The last section summarizes the main conclusions.

\section{Theoretical Background - Frugal Innovation}

The definition of frugal innovation is "a new management philosophy which integrates specific needs at the bottom of the pyramid markets as a starting point and works backward to develop appropriate solutions which may be significantly 
different from existing solutions designed to address the needs of upmarket segments" (Gusta, 2011). In Nunes and Breene's (2011) view, it is an offer, made specifically to low-income market segments. Despite the fact that Berm and Ivens (2013) distinguish between frugal and reverse innovations in their conceptual framework, both types can be potential tools for improving businesses in the ways they use resources, add value, generate outcomes, all of them result in sustainability performance and market performance (Bencsik \& Juhász, 2014).

Fukuda and Watanabe (2011) suggest that businesses have to deal with people in emerging economies as innovators or producers, not as consumers. That is to say, businesses have to pay more and a different kind of attention to their main stakeholders, and companies have to learn this new practice.

Table 1. The principles of frugal innovation in the Radjou and Prabhu model (2015)

\begin{tabular}{ll}
\hline \multicolumn{1}{c}{ Principle } & \multicolumn{1}{c}{ Meaning } \\
\hline Engage and iterate & customers are involved in interactions \\
\hline Flex your assets & $\begin{array}{l}\text { production, logistics, services are supported by } \\
\text { value chain }\end{array}$ \\
\hline $\begin{array}{l}\text { Creating sustainable } \\
\text { solutions }\end{array}$ & consumption of new product or service \\
\hline $\begin{array}{l}\text { Shaping customer } \\
\text { behaviour }\end{array}$ & $\begin{array}{l}\text { brand loyalty, improve market share and make } \\
\text { customers good with less consumption }\end{array}$ \\
\hline Co-create with prosumers & $\begin{array}{l}\text { co-operation and crowdsourcing provide help to } \\
\text { collective demands and skills of customers; R\&D } \\
\text { and marketing managers have an important role }\end{array}$ \\
\hline Making innovative friends & R\&D would be networked, lean, flexible \\
\hline
\end{tabular}

Source: based on Prasad, 2015, own construction

Zeschky and his colleagues (2014) established the three-level model of resource-constrained innovation, which contains cost innovation, good-enough innovation, and frugal innovation (see Figure 1). To create their construction, they used the Ansoff matrix to categorize the examples examined:

- Cost innovation ("same for less"): low scores on the market as well as technical novelty dimensions. This is based on available components, the key success factor being process capabilities such as managing production facilities in low-cost regions.

- Good-enough innovation ("tailored for less"): low-medium scores on both the market and technical novelty dimensions. This product and market innovation requires additional knowledge of technology and customers as well as an acceptable price on the market.

- Frugal innovation ("new for less"): medium-high scores on the market as well as technical novelty dimensions. Development of existing products with 
new parameters or creating a completely new product for resource-constrained markets, often by the contribution of a local team.

The above innovations are built on one another and all of them lead a reverse innovation, which "refers to a market rather than a product concept" (Zeschky et al., 2014, p. 23).

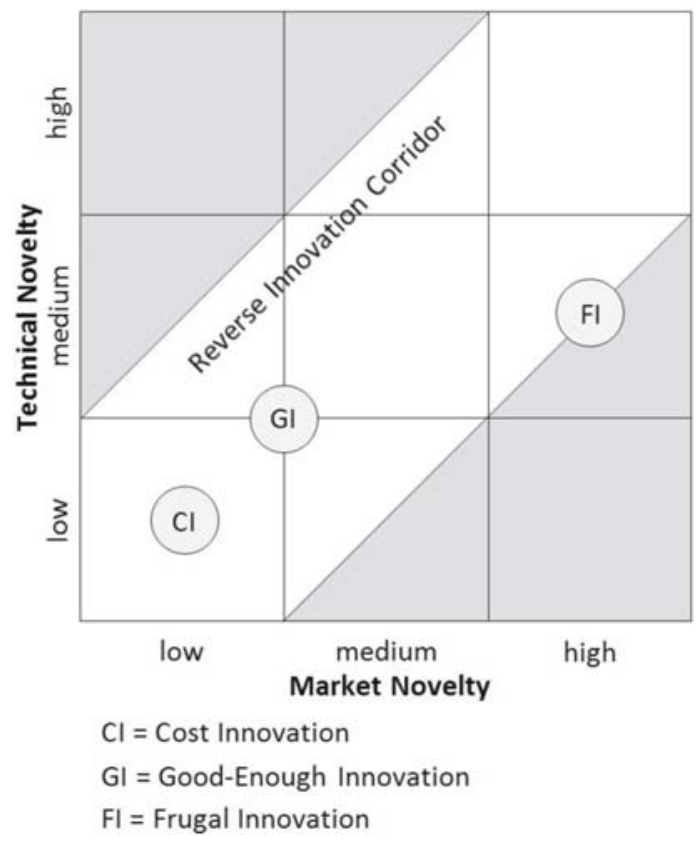

Source: Zeschky et al., 2014, p. 22

Figure 1. The resource-constrained innovation matrix

Based on the above references, the research question is: Are Hungarian businesses ready to introduce frugal innovation? To answer this question, the following hypothesis has been created:

No matter how short Hungarian businesses are of resources, they are not ready for frugal innovation.

\section{Material and Methods}

The primary quantitative survey took place at the beginning of 2015 (FebruaryMarch). The collection of data was in a simple, random way. The chapters of the simply structured questionnaire were:

- Innovations;

- Market Competition; 
- Frugal Innovation;

- Business Strategy;

- Co-operation;

- Balanced Scorecard (BSC);

- Background Information.

This paper focuses only on the Innovations chapter of the questionnaire.

The questionnaire contains closed and some open-ended questions. In order to answer the attitude-related questions, the 5-grade Likert scales were used for lucidity. There were some nominal scales as well. The data were analysed with MS Excel and SPSS programmes. Several statistical methods were used. Apart from the simple descriptive statistics necessary to present the results (arithmetical average, frequency, and cross table), main component analysis was conducted.

The main component analysis reduces the number of variables with a minimal loss of information. It is necessary to use it if the number of variables is too high and the aim is to reveal the structure of said variables.

During the selection, certain variables may correlate with factors which have nothing to do with them. These factors are rotated, that is their axes are turned into a simpler and more easily interpretable solution. Similarly to factor analysis, communality expresses what percentage of the variable is explained by the factor in total. Variables with a communality value of less than 0.25 may be left out of the analysis because they do not fit into the figure system. During the later stages of factor analysis, the elements appearing in the diagonal of the anti-image matrix (MSA-values) are taken into consideration because these elements show how close relationship will be between a given variable and other variables. The Bartlett-test was used to examine whether it is only a coincidence if the elements outside the main diagonal of the correlation matrix deviate from the 0 value. On the other hand, the Kaiser-Meyer-Olkin (KMO) criterion shows to what degree the variables are suitable for factor analysis, and its value is the average of the anti-image matrix MSA values. KMO $<0.5$ is an unacceptable value (Sajtos and Mitev, 2007).

\section{Results and Discussion}

\subsection{Specification of the Sample}

The questionnaire was filled in by 216 businesses. Based on the EC description related to the number of employees, there are multi-size enterprises in the sample:

- half of them (56\%) are micro-sized enterprises (0-9 employees),

- cc. one-fourth (24\%) are small-sized enterprises (10-49 employees),

- every tenth (10\%) is a medium-sized enterprise (50-249 employees),

- every tenth $(10 \%)$ is a large company (250+ employees). 


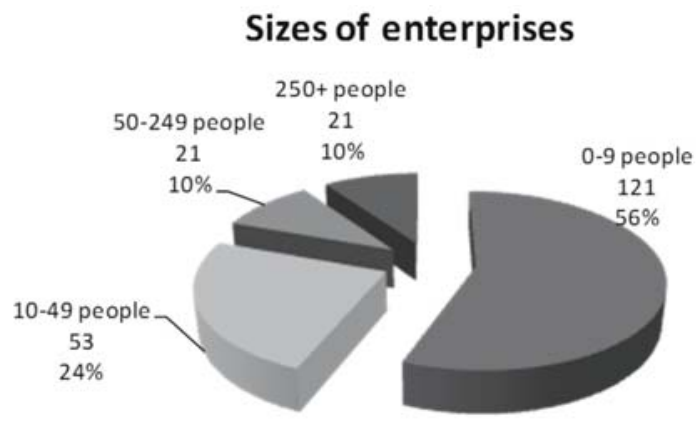

Source: own construction

Figure 2. Categories of businesses based on their number of employees

The surveyed businesses had been operating in several professional fields:

$-(A+B)$ agriculture, forestry, and fishing (9 enterprises, 4.1\%),

- (C) mining (1 enterprise, $0.5 \%$ ),

- (D) manufacturing (23 enterprises, 10.6\%),

- (E) energy (6 enterprises, $2.8 \%$ ),

- (F) construction (23 enterprises, 10.6\%),

- (G) wholesale, retail trade (67 enterprises, 30.9\%),

- (H) HORECA (14 enterprises, 6.5\%),

- (I) transport, post, storage, communication (20 enterprises, 9.2\%),

- $(\mathrm{J}+\mathrm{K})$ business activity, real estate, renting (27 enterprises, $12.4 \%$ ),

- (M) education (3 enterprises, $1.4 \%$ ),

- (N) health care and social work (8 enterprises, 3.7\%),

- anonymous (16 enterprises, $7.5 \%$ ).

From a regional point of view, more than half of the businesses had been operating in the capital. In addition, the sample contains businesses from every other region as well.

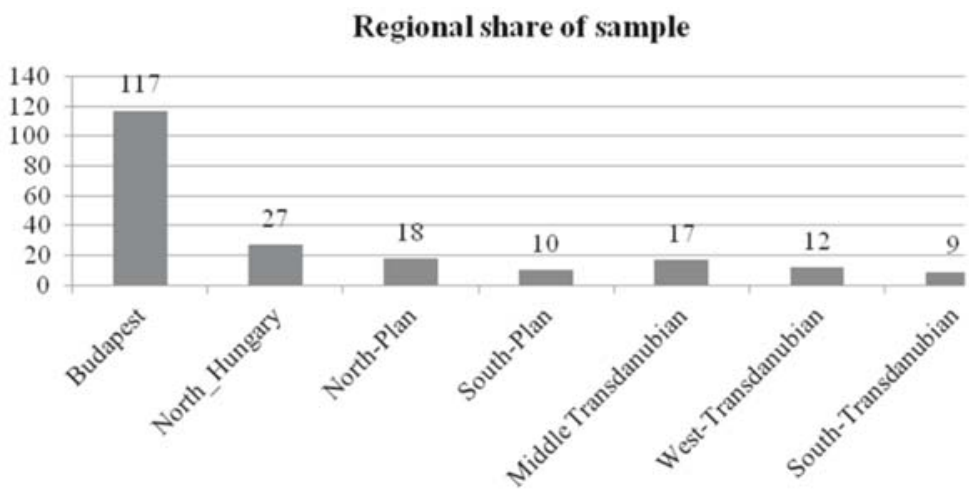

Source: own construction

Figure 3. Regional share of businesses 
The enterprises surveyed had been operating as follows:

- 0-3 years 30 businesses $(14.2 \%)$,

- 4-10 years 46 businesses $(21.8 \%)$,

- more than 10 years 135 businesses (64\%).

\subsection{Analysis of Hypothesis: No Matter How Short Hungarian Businesses Are of Resources, They Are Not Ready for Frugal Innovation}

As a first step, the surveyed businesses stated the meaning of innovation. According to the number of their choices, innovation means:

- new products (48 items, $22.1 \%$ ),

- new technology (52 items, 24\%),

- new market (33 items, 15.2\%),

- new sources of resources (12 items, 5.5\%),

- new organization (8 items, 3.7\%),

- all of the above mentioned (33 items, 15.2\%).

The next question was the necessity of innovating and its implementation in the previous three years in the operation of business. Table 2 clearly shows that there is no idea or need for innovating in every fifth business, and in many enterprises the necessity of innovating had emerged but was not followed through.

Table 2. Innovation in the past of the operation

\begin{tabular}{cccc}
\hline $\begin{array}{c}\text { Fields of } \\
\text { innovation }\end{array}$ & Did not emerge & $\begin{array}{c}\text { Emerged but did } \\
\text { not follow }\end{array}$ & $\begin{array}{c}\text { Emerged and } \\
\text { implemented }\end{array}$ \\
\hline \multirow{2}{*}{ Production } & 37 & 30 & 132 \\
& $17.1 \%$ & $13.8 \%$ & $60.8 \%$ \\
\hline \multirow{2}{*}{ Sales } & 49 & 33 & 110 \\
& $22.6 \%$ & $15.2 \%$ & $50.7 \%$ \\
\hline
\end{tabular}

According to the surveyed businesses, half of them (115 enterprises, 53\%) realized some sort of technological innovation. Two-thirds of the businesses (149 enterprises, $68.7 \%$ ) entered a new market.

The next step is the examination of organizational attitudes towards the question of frugal innovation, particularly creating sustainable solutions for customers and shaping their behaviour. The results clearly tell us that the surveyed businesses understand that there is no innovation without the customers' awareness or without the skill of adaptability. However, these businesses are deeply split on their ability to compete with simple, reliable, and cheap products on the market. The same uncertainty appears on the issue as to whether innovation leads to cheaper products/services for customers or not. Less than half of the businesses 
agree with the statement that "it is possible to create high levels of added value from little money". And, finally, only one third (37.6\%) can imagine that they would be able to develop continuously and sustainably with scarce resources. Likewise, they are uncertain of a strategy which would create more value with less work and material.

Table 3. Positive attitudes of businesses towards the principles of frugal innovation

\begin{tabular}{|c|c|c|c|c|c|}
\hline Principles & $\begin{array}{c}\text { Micro-sized } \\
\text { enterprises }\end{array}$ & $\begin{array}{l}\text { Small-sized } \\
\text { enterprises }\end{array}$ & $\begin{array}{l}\text { Medium- } \\
\text { sized enter- } \\
\text { prises } \\
\end{array}$ & $\begin{array}{c}\text { Large } \\
\text { compa- } \\
\text { nies }\end{array}$ & $\begin{array}{l}\text { Al- } \\
\text { together }\end{array}$ \\
\hline $\begin{array}{l}\text { Part of innovation is better / more } \\
\text { knowledge about customers. }\end{array}$ & $\begin{array}{c}104 \\
86.6 \% \\
\end{array}$ & $\begin{array}{c}46 \\
86.7 \% \\
\end{array}$ & $\begin{array}{c}15 \\
75.0 \% \\
\end{array}$ & $\begin{array}{c}18 \\
85.7 \% \\
\end{array}$ & $\begin{array}{c}183 \\
85.5 \% \\
\end{array}$ \\
\hline $\begin{array}{l}\text { Adaptability is a criterion of } \\
\text { innovation. * } \\
\text { sig=0.029; } \chi^{2}=0.170\end{array}$ & $\begin{array}{c}102 \\
85.8 \%\end{array}$ & $\begin{array}{c}45 \\
84.9 \%\end{array}$ & $\begin{array}{c}15 \\
71.4 \%\end{array}$ & $\begin{array}{c}19 \\
90.4 \%\end{array}$ & $\begin{array}{c}181 \\
84.6 \%\end{array}$ \\
\hline $\begin{array}{l}\text { Businesses have to meet every } \\
\text { demand of customers. }\end{array}$ & $\begin{array}{c}83 \\
69.1 \% \\
\end{array}$ & $\begin{array}{c}41 \\
77.3 \% \\
\end{array}$ & $\begin{array}{c}9 \\
42.9 \% \\
\end{array}$ & $\begin{array}{c}18 \\
85.7 \% \\
\end{array}$ & $\begin{array}{c}151 \\
70.2 \% \\
\end{array}$ \\
\hline $\begin{array}{l}\text { In the competition with MNCs, it } \\
\text { is necessary to make lean products } \\
\text { with minimal resources and money. } \\
\text { These products are easy to use; they } \\
\text { are simple and reliable regarding } \\
\text { their technological aspects and } \\
\text { cheaply manufactured. }\end{array}$ & $\begin{array}{c}79 \\
65.9 \%\end{array}$ & $\begin{array}{c}36 \\
69.3 \%\end{array}$ & $\begin{array}{c}10 \\
47.5 \%\end{array}$ & $\begin{array}{c}15 \\
75.0 \%\end{array}$ & $\begin{array}{c}140 \\
65.8 \%\end{array}$ \\
\hline $\begin{array}{l}\text { Innovation brings down the price of } \\
\text { products, making them affordable to } \\
\text { customers. }\end{array}$ & $\begin{array}{c}78 \\
65 \%\end{array}$ & $\begin{array}{c}36 \\
67.9 \%\end{array}$ & $\begin{array}{c}11 \\
52.4 \%\end{array}$ & $\begin{array}{c}15 \\
71.4 \%\end{array}$ & $\begin{array}{c}140 \\
65.1 \%\end{array}$ \\
\hline $\begin{array}{l}\text { It is possible to create a high level of } \\
\text { added value with little money. }\end{array}$ & $\begin{array}{c}65 \\
54.6 \% \\
\end{array}$ & $\begin{array}{c}17 \\
32.0 \% \\
\end{array}$ & $\begin{array}{c}11 \\
52.4 \% \\
\end{array}$ & $\begin{array}{c}8 \\
38.1 \%\end{array}$ & $\begin{array}{c}101 \\
47.2 \%\end{array}$ \\
\hline $\begin{array}{l}\text { A business is able to develop } \\
\text { continuously and sustainably with } \\
\text { scarce resources. }\end{array}$ & $\begin{array}{c}49 \\
40.8 \%\end{array}$ & $\begin{array}{c}15 \\
28.3 \%\end{array}$ & $\begin{array}{c}10 \\
47.6 \%\end{array}$ & $\begin{array}{c}7 \\
33.4 \%\end{array}$ & $\begin{array}{c}81 \\
37.6 \%\end{array}$ \\
\hline $\begin{array}{l}\text { A strategy is feasible which creates } \\
\text { more products from less work and } \\
\text { material. }\end{array}$ & $\begin{array}{c}35 \\
29.2 \%\end{array}$ & $\begin{array}{c}16 \\
30.8 \%\end{array}$ & $\begin{array}{c}7 \\
33.4 \%\end{array}$ & $\begin{array}{c}10 \\
47.6 \%\end{array}$ & $\begin{array}{c}68 \\
31.8 \%\end{array}$ \\
\hline
\end{tabular}

Source: own construction

If the above statements are reduced, they will have to be collapsed into three factors, which explain $69 \%$ of the variables. The first factor contains the statements of commitment to sustainable development and shows the power of (non-financial) resources of businesses. The second factor includes the statements made in response to tendencies in the environment. Finally, the third factor refers to the strong competition on the markets and implies eagerness to make profit. 
Table 4. The Rotated Component Matrix of attitudes toward frugal innovation*

\begin{tabular}{|c|c|c|c|c|}
\hline \multirow{2}{*}{ Factors } & \multirow{2}{*}{ Principles } & \multicolumn{3}{|c|}{ Component } \\
\hline & & 1 & 2 & 3 \\
\hline \multirow{2}{*}{$\begin{array}{l}\text { Power of } \\
\text { sources }\end{array}$} & $\begin{array}{l}\text { A business is capable of continuous and } \\
\text { sustainable development with scarce } \\
\text { resources. }\end{array}$ & .835 & .002 & .086 \\
\hline & $\begin{array}{l}\text { It is possible to create a high level of } \\
\text { added value with little money. }\end{array}$ & .815 & .051 & -.012 \\
\hline \multirow{2}{*}{$\begin{array}{l}\text { Environment- } \\
\text { orientation }\end{array}$} & $\begin{array}{l}\text { Part of innovation is better / more } \\
\text { knowledge about customers. }\end{array}$ & -.031 & .843 & -.026 \\
\hline & Adaptability is a criterion of innovation. & .084 & .835 & .011 \\
\hline \multirow[b]{2}{*}{$\begin{array}{l}\text { Products for } \\
\text { everyone }\end{array}$} & $\begin{array}{l}\text { Businesses have to meet customers' every } \\
\text { demand. }\end{array}$ & -0.142 & -.008 & .828 \\
\hline & $\begin{array}{l}\text { In the competition with MNCs, it is } \\
\text { necessary to make lean products with } \\
\text { minimal resources and money. These } \\
\text { products are easy to use; they are simple } \\
\text { and reliable regarding their technological } \\
\text { aspects and cheaply manufactured. }\end{array}$ & .241 & -.007 & .770 \\
\hline
\end{tabular}

$\mathrm{KMO}=0.510$; sign. $<0.000$, the cumulative extraction sums of squared loadings $69.073 \%$

Source: own construction

According to the surveyed businesses, the business model which pursues the goal of frugality and simplicity combined with good quality and low prices is:

- unfeasible (8 enterprises, 3.7\%),

- probably feasible (57 enterprises, 26.4\%),

- undecided about the question (83 enterprises, 38.4\%),

- likely feasible (56 enterprises, $25.8 \%$ ),

- absolutely certain of feasibility (12 enterprises, 5.5\%).

Despite of uncertainty businesses, more than half of enterprises $(55.8 \%)$ proclaim that they follow the mentioned strategy.

\section{Conclusion}

As far as the share of small- and medium-sized enterprises (SME-s) is concerned, the rate of micro-enterprises is higher (94.5\%) than the EU average (92.4\%). They employ less people, an average of 3.1 people compared to the EU average of 4.2 (SME Annual book, 2011). The added value created in the Hungarian SME sector is lower by $5 \%$ than the average with the other EU members. Enterprises operate in a difficult economic situation characterized by high taxes and social insurance charges, unpredictable economic regulation, high administrational fees and inadequate demand (KSH, 2013). The majority of the SME-s focus on the 
domestic market, their activity mostly depending on the larger-sized enterprises. Medium-sized companies supply those which in turn outsource their services (Gyulai, 2013). The birth-rate of SME-s was only $8.6 \%$ in 2012, while their survival rate was $56.74 \%$ (Eurostat).

Although approximately two-thirds of the businesses interviewed had been operating for more than ten years, a high number of them stated that innovation was not an option or, where it was, it was not realized in the field of production or sales. They view mainly in terms of innovation the novelty of products $(22.1 \%)$ or that of technology $(24.0 \%)$. The concept of innovation as market novelty is shared only by $15.2 \%$. If we take that $15.2 \%$ of the businesses which consider all the types mentioned to be innovation, the result is not too promising. Even if the businesses are aware of the requirements for innovation, such as knowledge of customers and adaptability, there is an obvious contradiction between the shared and followed values. Theoretically, they know very well the importance of customers' awareness and skills of adaptability for being in competition, but they practically cannot carry out innovations.

In terms of strategy, only two-thirds of the opinions (65.8\%) reflect that they can compete with multinational companies realizing frugal innovations (produce simple, reliable, and lean products at low cost and price). In their judgement, to distinguish themselves from the mass products of large (multinational) companies, the SMEs have their own (higher) price and have to meet the needs and requirements of one or few segments only. Their strategy is in connection with the demands of customers as well as the processes and costs of production. These are the reasons why businesses almost cannot believe in continuous and sustainable development with scarce resources $(31.8 \%)$ or in the possibility of creating high levels of added value with little money (47.2\%). If they suffer from starvation of profit, they find it too difficult to adopt a strategy which would create more products and values from less work and fewer resources, what is unthinkable for the surveyed micro-, small-, and medium-sized enterprises. To summarize our examination, the formulated hypothesis is verified because the inquired Hungarian businesses are not ready for frugal innovation.

\section{References}

Balkrishna, C. R. (2014). Alleviating poverty in the twenty-first century through frugal innovations. Challenge 57(3), May/June: 40-59.

Bencsik, A.; Juhász, T. (2014). Innováció és tudásmenedzsment a szervezetekben. In: Juhász György; Šeben Zoltán; Dobai Korcsmáros Enikő; Huszárik Seres Erika (eds), Oktatás és tudomány a XXI. század elején: A komáromi Selye János Egyetem 2014-es Nemzetközi Tudományos Konferenciájának tanulmánykötete 
[Vzdelávanie a veda na začiatku XXI. storočia: Zborník z medzinárodnej vedeckej konferencie Univerzity J. Selyeho - 2014]: Gazdaságtudományi Szekció.

Brem, A.; Ivens, B. (2013). Do frugal and reverse innovation foster sustainability? Introduction of a conceptual framework. Journal of Technology Management for Growing Economies 4(3), October: 31-50.

Csath, M. (2015). A fenntartható fejlődés feltételei. http://mno.hu/velemeny/afenntarthato-fejlodes-feltetelei-1283321. Last accessed on: 24.04.2015.

Fukuda, K.; Watanabe, Ch. (2011). A perspective on frugality in growing economies: triggering a virtuous cycle between consumption propensity and growth. Journal of Technology Management for Growing Economies 2(2), October: 79-98.

Gupta, V. P. (2011). Frugal innovation. The new masters of management. In: 'Jugaad' to Frugal Innovation. Indian MBA. Retrieved from: http://www. indianmba.com/Faculty_Column/FCI283/fc1283.html

www.ksh.hu

Nunes, P. F.; Breene, T. S. (2011). Jumping the S-Curve. How to beat the growth cycle, get on top, and stay there. Harvard Business Review Press, Harvard.

Prasad, S. (2015). How to do better with less. Recension of frugal innovation (Radjou, N.; Prabhu, J.), Hachette, India, BUSINESS TODAY April 26. 2015., p. 116.

Sajtos, L.; Mitev, A. (2007). SPSS kutatási és adatelemzési kézikönyv. Budapest: Alinea.

NTH (2013). Kkv évkönyv, 2011. Kis- és középvállalkozások stratégiája 20142020. Társadalmi egyeztetésre készített tervezet. (SMEs Annual Book, 2011. Strategy of SMEs 2014-2020). www.nth.gov.hu/hu/media/download/256. Downloaded on: 08.2015.

Srinivas, S.; Sutzs, J. (2008). Developing countries and innovation: searching for a new analytical approach. Technology in Society 30: 129-140.

Tóth, G. (2007). A Valóban Felelős Vállalat. (The real responsible company). Budapest: KÖVET. Retrieved from: http://www.otlethid.hu/doc/VFV.pdf.

Zeschky, M. B.; Winterhalter, S.; Gassmann, O. (2014). From cost to frugal and reverse innovation: mapping the field and implications for global competitiveness. Research-Technology Management July-August: 20-27.

Zeschky, M.; Widenmayer, B.; Gassmann, O. (2011). Frugal innovation in emerging markets: the case of mettle. Research-Technology Management 54(4): 38-45.

www.eurostat.com 